Ihssan F Al-Takai

BDS, MSc (Asst. lec.)

\section{The Effect of Different Disinfectant Solutions on Shear Bond Strength of Acrylic Teeth to Flexible Denture Base Material}

Department of Prosthodontic

College of Dentistry, University of Mosul

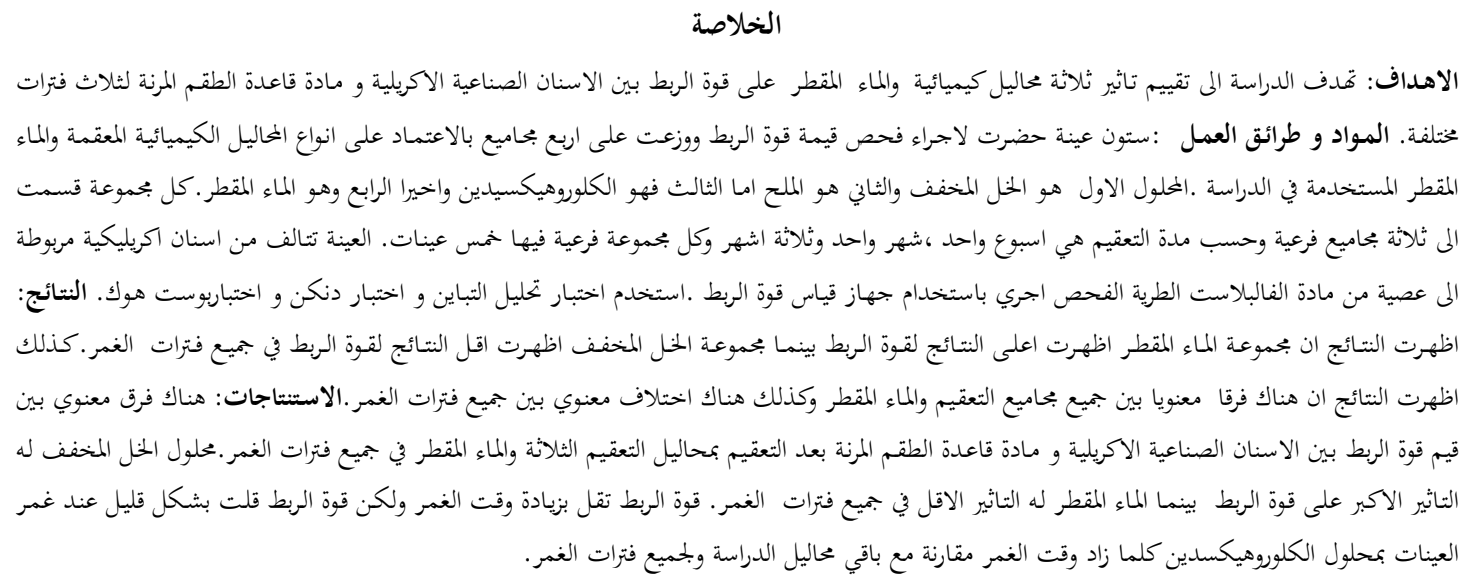

ABSTRACT

Aims: is to evaluate the effect of three different disinfectant solutions on shear bond strength of artificial acrylic teeth for retention to flexible denture base material at three different periods of time. Materials and Methods: The total number of samples was (60) divided into 4 groups according to the three chemical disinfectant solution which used and the control distilled water group: Group( I) vinegar group, Group( II) salt group , Group(III) Chlorohexidine group , Group (IV ) the control distilled water group, where each group was subdivided into three subgroups according to disinfection periods which are 1 week, 1 month and 3month where each group contain five samples. The samples of shear bond strength test were consist of acrylic teeth with T-shape design for retention attached to rod of valplast The test was performed using a Universal testing machine. ANOVA, Duncun's multiple range and Post Hoc Tests were carried out to determine the significant difference at $p \leq 0.01 \%$. Results: The results appeared that control distilled water group has the highest value for the three periods of disinfection ( 1 week,1month,3months), while vinegar solution group has the least value. The results showed that there were significant differences between the four tested groups and also there were significant differences among all periods of time of disinfections. Conclusion: There was a significant difference of shear bond strength between artificial teeth and flexible denture base material after disinfection in the four disinfectant solutions for all periods of time of immersion. Vinegar group had highest effect on the bond strength while the distilled water group had the least effect after all periods of time of disinfections. Shear bond strength decreased with increasing the time immersion. The shear bond strength was lowest in chloherxidine group as the time of immersion increase when compared with the two other groups of disinfection solutions in this study.

Key words: Flexible denture, shear bond.

Al-Takai IF. The Effect of Different Disinfectant Solutions on Shear Bond Strength of Acrylic Teeth to Flexible Denture Base Material. Al-Rafidain Dent J. 2014; 14(1): 145-152.

Received: 10/4/2013 Sent to Referees: 18 /4/2013

\section{INTRODUCTION}

Thermoplastic materials for dental prostheses, Valplast and Flexiplast, were first introduced to dentistry in the 1950s. Both materials were similar grades of
Polyamides (nylon plastics). Valplast is a pressure injected at a temperature of $274^{\circ} \mathrm{C}-300^{\circ} \mathrm{C}$. Flexible denture base resin that is ideal for partial dentures and unilateral restorations. No tooth or tissue 
preparation is needed. ${ }^{(1-5)}$ Flexible denture base material is a nylon based (polyamide) thermoplastic denture base material. It is flexible, nearly unbreakable, pinkcoloured like gums, can be built quite thin, and can form not only the denture base, but also the clasps as well .The thermoplastic material has a unique property that it does not chemically bond with any of the acrylic resin / porcelain teeth, so mechanical bonding is the only mode to use in the polyamide denture base material. Sufficient height of the selected teeth is required for mechanical bonding. Mechanical undercuts (diatorics) should be made in the centre of each tooth so that melted fluid polyamide could flow into the undercuts so as to retain the tooth in the denture. ${ }^{(6-9)}$ There are several types of RPDs, all of them use standard denture teeth as replacements for the missing natural teeth. Denture hygiene is essential to maintain the service ability of the denture because of esthetic concerns. Because of that the most effective preventive and curative treatment for pathogens is believed, denture cleansers have been studied to identify the ideal product. ${ }^{(10)}$ Dentures can be cleaned mechanically, chemically or through a combination of these. ${ }^{(11)}$ Chlorhexidine gluconate is a cationic oral antiseptic agent with bactericidal activity and acts by destabilizing and penetrating in bacterial cell membranes. It has been widely used due to its antiseptic and antimicrobial effects in oral and dental diseases. ${ }^{(12)}$ The use of vinegar solution was effective in

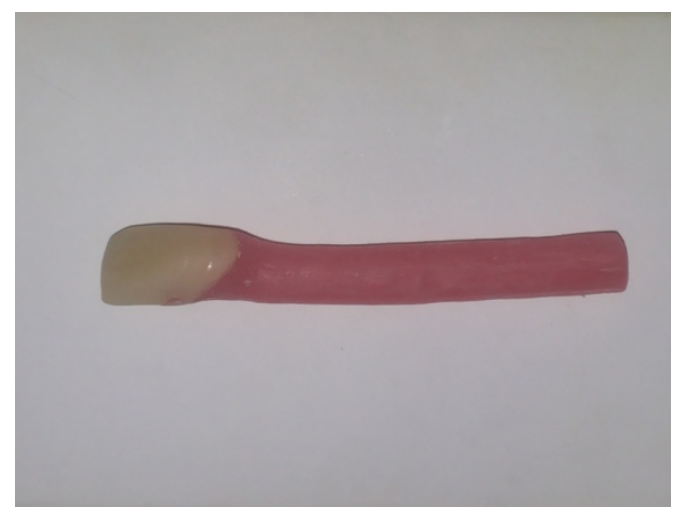

Figure (1): Sample of tooth for shearbond

preparation were made using carbide fissure bur. After that $5 \mathrm{~mm}$ end of the wax killing adherent microorganisms. ${ }^{(13)}$ Disinfection by resilient liner in sodium chloride solution proved a more effective method than exposure to microwave energy. ${ }^{(14)}$ Aim of this study is to evaluate the effect of three different disinfectant solutions (acetic acid, $\mathrm{NaCl}$ and chlorhexidine)for three periods of time (1 week, 1 month and three months) on shear bond strength of artificial acrylic teeth to flexible denture base.

\section{MATERIALS AND METHODS}

The sample for the shear bond strength test consist of an acrylic teeth, central incisor (Meheco, China) which prepared and attached to it a rod of Valplast (China) $5 \mathrm{~mm}$ in radius and 2.5 $\mathrm{cm}$ in length ${ }^{(15)}$ as shown in Figure (1).

The $\mathrm{T}$ mechanical designs were prepared in the center of the ridge lap surface of the acrylic teeth as shown in Figure (2).T-shape design has the highest value for increase retention means with flexible base, this can be explained in that, Valplast relies solely on mechanical retention to retain the teeth and if there is not enough room to place retention holes in the teeth, they can become displaced overtime (16), the detachment may be attributed to lesser ridge lap surface area available for bonding and direction of stress encountered during function. ${ }^{(17)}$ This design is prepared as $\mathrm{T}$ - shape(diatorics) with dimension $2.5 \mathrm{~mm}$, 3mm (width, depth respectively) with lateral extension $1 \mathrm{~mm}$ in width as shown in Figure (2). The

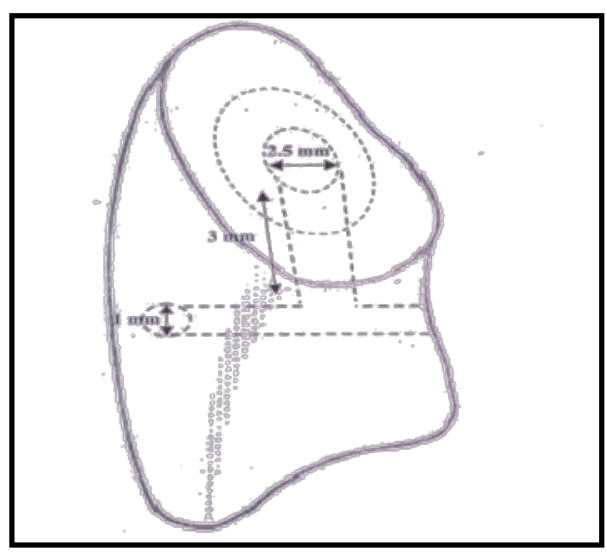

Figure (2): Mechanical retention means T-shape

pattern was placed on the ridge lap surface of the acrylic teeth. Then the combination 
of the acrylic tooth and the wax pattern was placed in denture flask to substitute the wax with Valplast and curing occurred with injected technique. Curing occurred with using chemical bonding agent (methyl methacrylate monomer). Monomer dissolves the tooth surface and forms a durable secondary semiinterpenetrating polymer networks (IPN) structure. ${ }^{(18-20)}$ A drop of monomer was applied with a small brush on the denture tooth surface for waiting time 60 seconds before packing. All specimens were stored at $37^{\circ} \mathrm{C}$ for 2 hours in distilled water before shear bond strength test has been performed. The total number of samples was (60) divided into 4 groups according to the three chemical disinfectant solution which used and the control distilled water group as shown in Table(1): Group(I) vinegar group, Group( II) salt group , Group(III) Chlorohexidinegroup , Group (IV ) the control distilled water group, where each group subdivided into three groups contained five samples and all these groups were disinfected at three time periods which are 1week, 1month and 3months.

Table (1): The Chemical Compounds, Concentrations used in the Study

\begin{tabular}{ccccc}
\hline No. & Type & Product & Conc.\% & Manufacture \\
\hline 1 & Dania (acetic acid) & Artificial clear vinegar & 5 & Jordan \\
2 & Sodium chloride (without & Salt & $40 \%$ & Iraq \\
& iodine) & Chlorohexidinegluconat & & Iraq \\
3 & Chlorohexidine gluconate & e & & Iraq \\
4 & Distilled water & Distilled water & & \\
\hline
\end{tabular}

Disinfection Procedures:

The disinfection method was as follow:

1. The samples of distilled water group were soaked for 1week, 1monthand 3 months in distilled water only for 8 hours per day at $37^{\circ} \mathrm{C}$ by using a clock timer then the samples were left dry.

2. The samples of saturated salt group were soaked for half an hour per day in saturated salt solution for 1 week, 1 month and 3 months then the samples were left dry.

3. The samples of Vinegar group were soaked for half an hour per day in vinegar solution for 1 week, 1month and 3 months then the samples were left dry.

4. The samples of CHX group were soaked for half an hour per day in CHX solution for 1 week, 1 month and 3 months then the samples were left dry.

All samples soaked in three different disinfectant solutions( acetic acid, $\mathrm{NaCl}$ and chlorohexidine ) half hour per day for three periods of time (1 week, 1month and three months). The testing performed on a Universal testing machine (Instron) and the samples were holded by using the device holder (clamp) as shown in Figure (3) .The load at fracture was recorded. ${ }^{(9)}$ Statistically mean and standard deviation were calculated. ANOVA, Duncan's multiple range test and Post Hoc Tests were carried out to determine the significant differences among tested groups at $p \leq 0.01$.

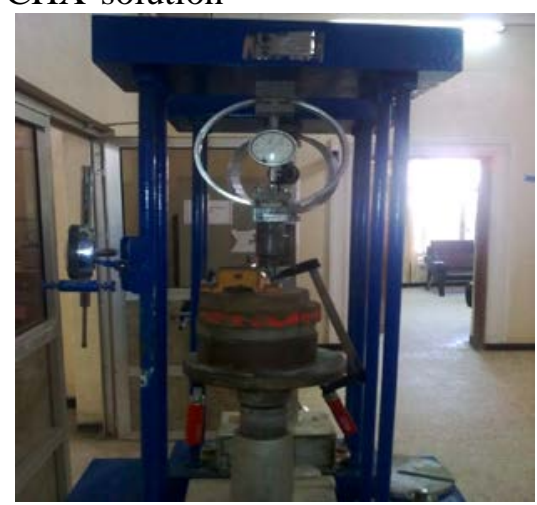

Figure (3): Universal testing machine(Instron) 


\section{RESULTS}

The most common clinical problem between the artificial teeth and denture base resin are bond failures at the interfacial region. ${ }^{(21)}$ Many factors can influence this bonding which includes chemical and mechanical preparation on ridge lap surface of tooth, the presence of impurities along tooth/ denture base interface due to poor laboratory techniques. ${ }^{(22)}$ The results in Table (2) appeared that Group (VI) control distilled water had the highest value for the three periods of disinfection (7, 30,90 days) (14.464 MPa, 14.162 MPa, 13.711 MPa respectively), while Group(I) vinegar solution had the least value (12.376MPa, 12.1182 MPa, 11.4268 MPa respectively).

Table (2): Mean and standard deviation of shear bond strength between artificial acrylic teeth and Valplast denture base materials for four tested chemical disinfectant solutions for three periods of times

\begin{tabular}{clccl}
\hline Time & Solutions & No & Mean (MPa) & SD \\
\hline \multirow{5}{*}{ 1week } & salt & 5 & 12.656 & 0.2006 \\
& Vinegar & 5 & 12.376 & 0.1238 \\
& Chx & 5 & 13.548 & 0.561 \\
& Distilled water & 5 & 14.464 & 0.4759 \\
& salt & 5 & 12.3770 & 0.2109 \\
1month & Vinegar & 5 & 12.1182 & 0.348227 \\
& Chx & 5 & 13.222 & 0.17444 \\
& Distilled water & 5 & 14.162 & 0.2856 \\
& salt & 5 & 12.0046 & 0.13802 \\
3month & Vinegar & 5 & 11.4268 & 0.12421 \\
& Chx & 5 & 12.9640 & 0.2729 \\
& Distilled water & 5 & 13.7110 & 0.457963 \\
\hline
\end{tabular}

No: number of samples SD: standard deviation

The results of ANOVA test and Post Hoc Tests in Tables $(3,4,5)$ showed that there is a significant difference of shear bond strength between three disinfectant solutions and the distilled water group among all periods of disinfections time.

Table (3): ANOVA of shear bond strength between artificial acrylic teeth and Valplast denture base materials between four tested chemical disinfectant solutions for three periods of times

\begin{tabular}{|c|c|c|c|c|c|c|}
\hline Time & Source of variance & $\begin{array}{l}\text { Sum of } \\
\text { square }\end{array}$ & DF & $\begin{array}{c}\text { Mean } \\
\text { square }\end{array}$ & F-value & $* * P$ value \\
\hline 1 week & $\begin{array}{c}\text { Between groups } \\
\text { Within groups } \\
\text { Total }\end{array}$ & $\begin{array}{l}13.399 \\
2.388 \\
15.787\end{array}$ & $\begin{array}{l}3 \\
16 \\
19\end{array}$ & $\begin{array}{c}4.466 \\
0.149 \\
4.269\end{array}$ & 29.93 & 0.000 \\
\hline 1month & $\begin{array}{c}\text { Between groups } \\
\text { Within groups } \\
\text { Total }\end{array}$ & $\begin{array}{l}12.808 \\
1.111 \\
13.919\end{array}$ & $\begin{array}{l}16 \\
19 \\
3\end{array}$ & $\begin{array}{l}0.069 \\
5.127\end{array}$ & 61.477 & 0.000 \\
\hline 3month & $\begin{array}{l}\text { Between groups } \\
\text { Within groups } \\
\text { Total }\end{array}$ & $\begin{array}{l}15.381 \\
1.275 \\
16.656\end{array}$ & $\begin{array}{l}3 \\
16 \\
19\end{array}$ & 0.080 & 64.351 & 0.000 \\
\hline
\end{tabular}

DF : degree of freedom, $\mathrm{P}^{* *}$ : Means are highly statistically significant different at $p \leq 0.01$ 
Table (4): Post Hoc Tests of shear bond strength between artificial acrylic teeth and Valplast denture base materials for four tested disinfectant solutions for three periods of times

\begin{tabular}{lccccc}
\hline \multirow{2}{*}{ Time } & \multicolumn{2}{c}{ (i)solution (J)solution } & Mean differences (i-j) & SE & $*$ ** -value \\
\hline 1week & Salt & Distilled water & -1.8084 & 0.244215 & $0.000^{* *}$ \\
& Vinegar & Distilled water & -2.0884 & 0.244215 & $0.000^{* *}$ \\
& Chx & Distilled water & -0.9164 & 0.244215 & $0.005^{* *}$ \\
\multirow{3}{*}{ 1month } & Salt & Distilled water & -1.785 & 0.1666 & $0.000^{* *}$ \\
& Vinegar & Distilled water & -2.0438 & 0.1666 & $0.000^{* *}$ \\
& Chx & Distilled water & -0.9400 & 0.1666 & $0.000^{* *}$ \\
3 & Salt & Distilled water & -1.7064 & 0.17851 & $0.000^{* *}$ \\
& Vinegar & Distilled water & -2.2842 & 0.17851 & $0.000^{* *}$ \\
& Chx & Distilled water & -0.7470 & 0.17851 & $0.002 * *$ \\
\hline
\end{tabular}

No: number of samples, ${ }^{* *}$ Means with different letters are highly statistically significant different at $p \leq 0.01 \%$

Table (5): ANOVA of shear bond strength between artificial acrylic teeth and Valplast denture base materials for four tested disinfectant solutions among three periods of times.

\begin{tabular}{|c|c|c|c|c|c|c|}
\hline Solution & Source of variance & $\begin{array}{l}\begin{array}{l}\text { Sum of } \\
\text { square }\end{array} \\
\end{array}$ & DF & Mean square & F-value & $* P$ value \\
\hline Salt & $\begin{array}{l}\text { Between groups } \\
\text { Within groups } \\
\text { Total }\end{array}$ & $\begin{array}{l}1.068 \\
0.415 \\
1.483\end{array}$ & $\begin{array}{l}2 \\
12 \\
14\end{array}$ & $\begin{array}{l}0.534 \\
0.035\end{array}$ & 15.433 & $0.000^{* *}$ \\
\hline Vinegar & $\begin{array}{l}\text { Between groups } \\
\text { Within groups } \\
\text { Total }\end{array}$ & $\begin{array}{l}2.409 \\
0.608 \\
3.017\end{array}$ & $\begin{array}{l}2 \\
12 \\
14\end{array}$ & $\begin{array}{l}1.205 \\
0.051\end{array}$ & 23.771 & $0.000 * *$ \\
\hline Chx & $\begin{array}{l}\text { Between groups } \\
\text { Within groups } \\
\text { Total }\end{array}$ & $\begin{array}{l}0.856 \\
1.679 \\
2.535\end{array}$ & $\begin{array}{l}2 \\
12 \\
14\end{array}$ & $\begin{array}{l}0.428 \\
0.140\end{array}$ & 3.061 & $0.044^{*}$ \\
\hline $\begin{array}{l}\text { Distilled } \\
\text { water }\end{array}$ & $\begin{array}{c}\text { Between groups } \\
\text { Within groups } \\
\text { Total }\end{array}$ & $\begin{array}{l}1.437 \\
2.071 \\
3.509\end{array}$ & $\begin{array}{l}2 \\
12 \\
14\end{array}$ & $\begin{array}{l}0.719 \\
0.173\end{array}$ & 4.164 & $0.042^{*}$ \\
\hline
\end{tabular}

DF : degree of freedom, $P^{*}$ : Means are highly statistically significant different at $p \leq 0.05$

${ }^{* *} p \leq 0.01, * p \leq 0.05$

The results of Duncan multiple range test in Table (6) for salt group appeared that there is a significant differences among all periods of time of disinfections, while in Table (7) for vinegar group the results appeared that there is a significant difference between 3 months with1 month and 1 week of disinfections, in Table (8) for Chx group the results appeared that there is a significant differences between 3 months and 1 week of disinfections, while in Table (9) for distilled water group the results appeared that there is a significant differences between 3 months and 1 week 
of disinfections.

Table (6) : Duncan's multiple range test for salt solution

\begin{tabular}{ccccc}
\hline Time & No & \multicolumn{3}{c}{ Subset for alpha=0.05 } \\
\cline { 3 - 5 } & & A & B & C \\
\hline 3 months & 5 & 12.005 & & \\
1 month & 5 & & 12.3770 & \\
1 week & 5 & & & 12.656 \\
\hline
\end{tabular}

Table (7) : Duncan's multiple range test for vinegar solution

\begin{tabular}{cccc}
\hline Time & No & \multicolumn{2}{c}{ Subset for alpha=0.05 } \\
\cline { 3 - 4 } & & A & B \\
\hline 3 months & 5 & 11.4268 & \\
1 month & 5 & & 12.1182 \\
1 week & 5 & & 12.376 \\
\hline
\end{tabular}

Table (8): Duncan's multiple range test for CHX solution

\begin{tabular}{cccc}
\hline Time & No & \multicolumn{2}{c}{ Subset for alpha=0.05 } \\
\cline { 3 - 4 } & & A & B \\
\hline 3 months & 5 & 12.964 & \\
1 month & 5 & 13.222 & 13.222 \\
1 week & 5 & & 13.548 \\
\hline
\end{tabular}

Table (9) :Duncan's multiple range test for Distilled Water

\begin{tabular}{cccc}
\hline Time & No & \multicolumn{2}{c}{ Subset for alpha=0.05 } \\
\cline { 3 - 4 } & & A & B \\
3 months & 5 & 13.711 & \\
1 month & 5 & 14.162 & 14.1620 \\
1 week & 5 & & 14.4644 \\
\hline
\end{tabular}

There are no previous studies to relate the result of this study to them. This result could be explained in that possible factors that influence solubility includes immersion time, concentration of solute in dissolution medium. ${ }^{(23)}$ also the high water sorption and solubility of materials decrease mechanical properties such as hardness, bond strength and fatigue limit. ${ }^{(24)}$ The lower value which was achieved with vinegar solution can be explained in that the clear vinegar is considered as acidic solvent leads to the softening of the surface layer of the material and decreases interchain forces and this will allow the water molecules to penetrate the material so, this factor will affect on the shear strength of the polymer, in addition the high acidity of the solution leads to an increase in water sorption and this in turn leads to an increase the plasticizing effect of the penetrated water molecules. ${ }^{(25)}$ The value which was achieved with salt group can be explained 
in that the saturated salt solution can leads to plasticization, which results in disentanglement crazing and embrittle the polymers, which is a reflection of its interaction with the polymer and lead to decrease the shear bond and tensile strength. These behaviors likely reflect the degree of interaction between the salts and the polymer, which again is a function of two forces, These forces are the plasticization of polymer by water, the complexation of salt with the polymer chain (the interference of hydrogen bond) and the degradation of the polymer with treatment .This reflected the amount of moisture absorbed by the samples. ${ }^{(26)}$ Other explanation is that the osmotic pressure created by $\mathrm{Na}+$ and $\mathrm{Cl}-$ ions will affect the leaching out of the polymer, in addition to that during disinfection, one or more environmental stress factors act on the bulk polymer. The effects of these stress factors are translated to the microscopic/molecular level where changes occur in the polymer network or chain. ${ }^{(27)}$ Yassin, ${ }^{(28)}$ concluded that the flexible material when left in distilled water has decreased in the bond strength of the material. The decrease in shear bond strength was lowest value in chlorhexidine group as the time of immersion increase when compared with other groups of disinfection in this study. This was in agreement with Naik (2005) ${ }^{(29)}$ and this may be due to that that highest molecular weight and the highest viscosity of the chlorhexidine incomparable to that of distilled water solution and this may decrease the absorption of chlorhexidine through the acrylic /flexible interface and this was lead to lowering the effect of chlorhexidine solution on the shear bond strength in compared to control distilled water solution, this could explain the highest value of tensile and shear strength and dimensional accuracy after that of control group as compared with that of experimental groups of $\mathrm{CHX}$ which show obvious change in these properties. ${ }^{(30)}$

\section{CONCLUSION}

There is a significant difference of shear bond strength between artificial teeth and flexible denture base material after disinfection in the four disinfectant solutions after all periods of time of immersion. Vinegar solution has highest effect on the bond strength while the distilled water solution has the least effect after all periods of time of disinfections. The shear bond strength was lowest in chloherxidine group as the time of immersion increase when compared with other two groups of disinfection in this study.

\section{REFERENCES}

1. Chittaranjan B, Aswini $\mathrm{K}$ and Taruna M. Management of A Case of Partial Edentulism with Esthetic Flexible Dentures. IJDA. 2009; 1(1): 60-62.

2. Renu T, Saurabh $G$ and Samarth $K$. Denture base materials: From past to future. Ind J Dent Scien. 2010; 2 ( 2 ) : 33-39.

3. Menaka A, Abuzar S and Nancy D. Evaluating surface roughness of a polyamide denture base material in comparison with poly (methyl methacrylate) J Oral Scien. 2010; 52(4): 577-581.

4. Singh JP, Dhiman RK and Bedi RPS. Flexible denture base material: A viable alternative to conventional acrylic denture base material. Contemporary Clinical Dentistry. 2012; 2(4) :313-317.

5. Pusz A, Szymiczek M and Michalik $\mathrm{K}$. Ageing process influence on mechanical properties of polyamide glass composites applied in dentistry. Journal of Achievements in Materials and Manufacturing Engineering. 2010; 38 (1): 49-55.

6. Prashanti E, Jain N and Shenoy VK. Flexible dentures: A flexible option to treat edentulous patients .J. Nepal Dent. Assoc. 2010; 11( 1): 85-87.

7. Anne P, Matthias $\mathrm{H}$ and Paul F. Bonding of acrylic denture teeth to MMA/PMMA and light-curing denture base materials: The role of conditioning liquids. $J$ dent. 2012; 40(3): 210-221.

8. Adelina E, Cosmin S and Mircea P. Tensile testing, a method used to demonstrate the effect of organic solvents on acrylic teeth denture base resin bond strength. Inter J Biology 
and Biomedical engineering. 2011; 5(1): 9-16.

9. Murat Kurt, Yakup S and Duygu S. Effect of pre-processing methods on bond strength between acrylic resin teeth and acrylic denture base resin. TheGerodontology Society and John Wiley \& Sons. 2011A/S: 1-6.

10. Mese A and Mese S. Effect of microwave energy on fungal growth of resilient denture liner material. Biotechnol 2007; 21: 91 - 93.

11. Shay K. Denture hygiene: a review and update. J Contemp Dent Prac 2000; 1 (2): 1 - 8.

12. Cal E, Guneri P and Kose T. Digital analysis of mouthrinses' staining characteristic on provisional acrylic resins. J Oral Rehabil 2007; 34: 297 303

13. Basson NJ, Quick AN and Thomas CJ. Household products as sanitizing agents in denture cleansing. $J$ Dent Assoc S Africa. 1992; 47:437.

14. Rathore P, Hegde A, Ginjupalli K and Upadhya PN. Evaluation of antifungal activity of additives to resilient liners: an in vitro pilot study. Trends BiomaterArtif Organs. 2009; 23(1): 69.

15. Abbas FA. An evaluation of the effect of retention means on increasing the debonding strength of the denture acrylic teeth attached to the denture base resin. Rest Dent. 2005; 17(1): 1417.

16. Michael D. Valplast, Flexible, esthetic partial dentures. Chair side.2004; 5 (1): 1-4.

17. Debora B B, Douglas Roberto M and Valentim A R. Effect of monomer treatment and polymerization methods on the bond strength of resin teeth to denture base materialo. The Gerodontology Society and Blackwell Munksgaard. 2009; 26: 225-231.

18. Fletcher $\mathrm{S}$ ML, Chung $\mathrm{KH}$ and Rubenstein JE. Shear bond strength of denture teeth to heat- and lightpolymerized denture base resin. $J$ Prosthodont. 2011; 20(1):52-9.

19. Nagle S, Ray NJ and Burke FM. Bonding auto-polymerizing acrylic resin to acrylic denture teeth. Eur $J$ Prosth Restor Dent. 2009;17(3):134-6.
20. Chaves C, Regis RR and Machado AL. Effect of ridge lap surface treatment and thermo-cycling on micro-tensile bond strength of acrylic teeth to denture base resin6s. Braz Dent J. 2009;20(2):127-31.

21. Meng GK, Chung KH and Fletcher SML. Effect of surface treatments and cyclic loading on the bond strength of acrylic resin denture teeth with autopolymerized repair acrylic resin. $J$ Prosthet Dent. 2010;103(4):245-52.

22. Ana C P, Juli M and Andr G . Measurement of Interfacial Porosity at the Acrylic Resin/Denture Tooth Interface. J Prosth. 2010;19: 42-46.

23. Yanikoglu $N$ and Duymus ZY. Evaluation of the solubility of dental cements in artificial saliva of different pH values. Dent Mater J. 2007; 26 (1): $62-67$.

24. Ergun G and Nagas IC. Color Stability of Silicone or Acrylic Denture Liners: An in Vitro Investigation. Eur J Dent. 2007; 1(1):144-151.

25. Khalil SM (2007): A Thesis. New Denture Cleansers. The Council of the College of Dentistry University of Mosul; Pp.61-63.

26. More AP and Donald AM. The effect of various salts on the mechanical properties of nylon. Polymer. 1993; 34( 34): 5093-5098.

27. Ottemer X (2001): Effects of Processing and Environmental Conditions on the Properties of Epoxy Materials, M.S. thesis, Georgia Institute of Technology, Atlanta, GA.Pp:259-263.

28. Yassin SA (2009):modified heat cured acrylic resin to flexible acrylic resin denture base material. M.Sc. Thesis, Collage of Dentistry, University of Mosul.

29. Naik NV and JabadJL.Comparision of Tensile bond Strength of Rwsilient Soft Liners to Denture Base Resin. $J$. Ind. Prosthet. 2005;5(2):234-239.

30. Sadoon M, Mohammed NZ and ALOmary A. Residual monomer and Transverse Strength Evaluation of Autopolymerized Acrylic Resin with Different Polymerization Treatment. AL-Rafidian Dent.J.2007;7:30-34. 
